\title{
Conservation of Betula oycoviensis, an endangered rare taxon, using vegetative propagation methods
}

\author{
Jan Vítámvás ${ }^{(1)}$, \\ Ivan Kuneš ${ }^{(1)}$, \\ Iva Viehmannová(2), \\ Rostislav Linda ${ }^{(1)}$, \\ Martin Baláš (1)
}

\begin{abstract}
Ojcow birch (Betula oycoviensis Besser) is a rare Central European tree taxon, micro-populations of which are found in only several localities. With a view to maintaining the $B$. oycoviensis gene pool, this study tested the species' potential for micropropagation, grafting, and propagation by cuttings. Plant material for vegetative propagation was collected from ten genotypes in the Czech Republic. In vitro culture was established from axillary buds surfaces sterilized with $0.1 \% \mathrm{HgCl}_{2}$ and cultivated on woody plant (WP) medium supplemented with $1 \mathrm{mg} \mathrm{l}^{-1}$ 6-benzylaminopurine (BAP). Two genotypes of the species were successfully multiplied by in vitro propagation using WP medium supplemented with 0-2 $\mathrm{mg} \mathrm{l}^{-1}$ BAP. The BAP concentration of $1 \mathrm{mg} \mathrm{l}^{-1}$ proved to be optimal, yielding 2.5 new shoots per explant in genotype 516 and 3.5 shoots per explant in genotype 545 . The shoots were rooted on half-strength Murashige and Skoog (MS) medium supplemented with various concentrations of a-naphthylacetic acid (NAA) and indole-3-butyric acid (IBA). The highest rooting percentages $(72.5 \%$ and $77.5 \%$ for genotypes 516 and 545 , respectively) were achieved on the medium with the combination of both auxins at concentrations of $0.3 \mathrm{mg} \mathrm{l}^{-1}$. The rooted plants were transferred ex vitro in substrate composed of sand, peat, and perlite $(1: 1: 1)$ and acclimated in the greenhouse. After 4 weeks, more than $90 \%$ of plants survived. Grafting was carried out in spring using Betula pendula as rootstock. The efficiency of this technique ranged from $0 \%$ to $50 \%$ across genotypes, and 4 out of 10 genotypes were successfully propagated by grafting. The cuttings were treated with commercial root stimulators Stimulax I and Stimulator AS-1, planted in a mixture of peat and sand $(1: 1)$ in the greenhouse, and watered regularly. This technique resulted in $0 \%$ rooting, however, and no cutting survived until the end of the vegetation period. The results of this study show that protocols for in vitro propagation and grafting can be employed for effective mass propagation of $B$. oycoviensis, although these processes show genotype-dependent responses.
\end{abstract}

\section{Keywords: Betula, Cutting, Grafting, In vitro Propagation, Rooting}

\section{Introduction}

Betula oycoviensis Besser is a rare and heretofore insufficiently researched taxon in the Czech Republic (Grulich 2012, Baláš et al. 2016), its occurrence being reported from only a few sites (Pladias, database of Czech flora and vegetation - https://plad ias.cz/en/). The only confirmed location of B. oycoviensis in the country is in a nature reserve near Volyně u Výsluní in the Ore Mountains (western Czech Republic). Na- tive distribution of Ojcow birch has been also reported for Poland, Ukraine, Russia, Denmark, Romania, and southern Sweden (Korczyk 1967, Krzaczek \& Krzaczek 1968, Staszkiewicz \& Wójcicki 1992, Staszkiewicz 2013, Buriánek et al. 2014).

In the nature reserve near Volyně u Výsluní, only a few dozen individuals exist. The natural regeneration of this population is slow, and many of the trees suffer from poor health conditions. Only a small per-
(1) Czech University of Life Sciences Prague, Faculty of Forestry and Wood Sciences, Kamýcká 1176, Praha 6 Suchdol (Czech Republic); (2) Czech University of Life Sciences, Faculty of Tropical AgriSciences, Kamýcká 129, Praha 6 Suchdol (Czech Republic)

@ Jan Vítámvás (vitamvas@fld.czu.cz)

Received: Sep 18, 2019 - Accepted: Jan 21, 2020

Citation: Vítámvás J, Kuneš I, Viehmannová I, Linda R, Baláš M (2020). Conservation of Betula oycoviensis, an endangered rare taxon, using vegetative propagation methods. iForest 13: 107-113. - doi: 10.3832/ifor3243-013 [online 2020-03-23]

Communicated by: Werther Guidi Nissim centage of individuals from the birch offspring bear the phenotype of the taxon, which is considered a hybrid species (Kubát et al. 2002, Kríž 2003). Although the taxonomic status of $B$. oycoviensis is not clear yet (Kuneš et al. 2019), it is crucial to maintain its extant populations both in the Czech Republic and elsewhere. This is important both in terms of maintaining the genetic diversity of this birch and to resolve its taxonomic status within our key taxonomic literature (Kubát et al. 2002, Kř́ž 2003, Kaplan 2019). B. oycoviensis is morphologically distinguishable from silver birch (Betula pendula), although a number of phenotypic transitions can be usually found in natural populations. In such cases, efforts should be undertaken to integrate ex situ conservation approaches and maintain endangered populations (Pritchard et al. 2014).

Micropropagation, especially via meristem culture, is an in vitro technology suitable for maintaining endangered birch genotypes through the rapid proliferation of clone planting material. In vitro methods are advantageous as opposed to conven- 
tional cuttings, especially in old plants where the formation of new shoots and roots can be more easily controlled and stimulated by the influence of substances added to the nutrient medium (De Diego et al. 2010, Sota \& Kongjika 2014). Microprop agation protocols have developed in recent decades for a large number of farm and ornamental tree species. However, each plant material needs to be tested on various culture media with the additions of plant growth regulators to optimize the growth of each individual. In this study, we used protocols formerly optimized for silver birch (B. pendula) as a starting point for B. oycoviensis propagation (Chalupa 1989, Särkilahti 1988, Ryynänen \& Ryynänen 1986, Viherä-Aarnio \& Velling 2001).

Propagation by cuttings proved difficult in birches (Hartmann \& Kester 1975), though partially successful results have been previously reported for several birch species. Pellett \& Alpert (1985) achieved a $60 \%$ success rate with rooted cuttings of Betula papyrifera. Marczynski \& Joustra (1993) studied the influence of length and light intensity on the survival and rooting of Betula utilis cuttings, achieving more than $90 \%$ success in rooting. In most cases, 2-3 years old trees grown from summer or winter cuttings have a chance to survive (Václav 1973, Hartmann \& Kester 1975, Marczynski \& Joustra 1993); however, this was not the case of our populations of B. oycoviensis.

Grafting is a propagation method demanding advanced manual skills. Tolerability of grafts and rootstocks to inosculation may vary substantially within the genus, and potential incompatibility has been reported among numerous combinations of rootstocks and grafts across different species, genera, and families (Darikova et al. 2011). Andrews \& Marquez (1993) reported potential factors that may contribute to rootstock and graft incompatibility, such as cellular recognition, wound response, growth regulators, and toxins. Moreover, inosculation failure may be caused by anatomical inconsistency, poor processing, environmental conditions, and diseases (Hartmann et al. 2002). Václav (1973) stated that the most commonly used combination in grafting birches is a union of an early sprouted rootstock and a winter graft of 2year-old wood, which typically inosculates within 2-3 weeks.

In this study, we tested the viability of the three vegetative propagation methods described above (in vitro organogenesis, grafting, and cutting) in order to obtain viable individuals from mature $B$. oycoviensis tree branches.

\section{Material and methods}

\section{Plant material}

As the initial plant material, branches 1-2 years old and bearing buds were used. The branches were collected from ten trees 4050 years old, numbered $34,511,516,518$,
520, 521, 540, 545, 533, and 552. Sampling was carried out in early spring (March) 2018 from the locality near Volyne village, in the vicinity of the town of Výsluní, Chomutov District, Czech Republic. All the collected material was stored in black polyethylene bags at $3-5{ }^{\circ} \mathrm{C}$ before its processing (grafting, cutting, in vitro culture). Experiments on $B$. oycoviensis propagation via cuttings and grafting were established the second day after branches were collected. Five days after the branches collection, the plant material was used for in vitro propagation. For grafting $B$. oycoviensis, containerized $B$. pendula seedlings 2-3 years-old were used as rootstock.

\section{In vitro culture}

Branchlets of B. oycoviensis were divided into one-nodal segments $1-2 \mathrm{~cm}$ long. The scales were removed from buds and the explants were washed in $200 \mathrm{ml}$ distilled water with addition of 1-2 drops of Tween $20^{\circledast}$ (Sigma-Aldrich, St. Louis, MO, USA) for $10 \mathrm{~min}$. The buds were then sterilized in $0.1 \% \mathrm{HgCl}_{2}$ for $6 \mathrm{~min}$, rinsed three times in sterile distilled water, and placed in $230 \mathrm{ml}$ baby food culture jars containing $30 \mathrm{ml}$ of woody plant (WP) medium (Lloyd \& McCown 1980) solidified with $8 \mathrm{~g} \mathrm{l}^{-1}$ Danish $^{\circledast}$ agar (Carl Roth, Karlsruhe, Germany), containing $100 \mathrm{mg} \mathrm{l}^{-1}$ myo-inositol, and supplemented with $1 \mathrm{mg} \mathrm{l}^{-1}$ 6-benzylaminopurine (BAP). After adjustment of $\mathrm{pH}$ to 5.7 , the medium was sterilized in an autoclave at $121^{\circ} \mathrm{C}$ and $118 \mathrm{kPa}$ for $30 \mathrm{~min}$. The explants were cultivated under $16 / 8 \mathrm{~h}$ light/dark photoperiod (photosynthetic photon flux density $35 \pm 2 \mu \mathrm{mol} \mathrm{m} \mathrm{m}^{-2}$ cool white fluorescent light), at temperature $24 \pm 1$ / $20 \pm 1$ ${ }^{\circ} \mathrm{C}$ (light/dark).

From each genotype, 20 explants were used after surface sterilization in two replications. The newly sprouted shoots were regularly subcultured every 2-3 weeks on the same medium until sufficient plant material was obtained. Dry, brown and contaminated explants were discarded during the in vitro cultivation.

\section{In vitro multiplication and rooting}

In vitro propagation experiment was carried out on segments of about $1.5 \mathrm{~cm}$ in length with two buds. The explants were cultivated on WP medium supplemented with $0.5,1$, and $2 \mathrm{mg} \mathrm{l}^{-1}$ BAP. As a control, plants grown on the medium without growth regulators were used. The in vitro cultures were kept under the cultivation conditions described above. After 8 weeks of cultivation, the shoot length, number of newly developed shoots, and approximate length of new shoots were evaluated. The intensity of callus development was also recorded.

The shoots developed in vitro were rooted on a half-strength MS medium (Murashige \& Skoog 1962) with addition of 0.3 or $0.5 \mathrm{mg} \mathrm{l}^{-1}$ indole-3-butyric acid (IBA), 0.3 or $0.5 \mathrm{mg} \mathrm{l}^{-1}$ a-naphthylacetic acid (NAA), or their combination $\left(0.3 \mathrm{mg} \mathrm{l}^{-1} \mathrm{IBA}+0.3 \mathrm{mg} \mathrm{l}^{-1}\right.$
NAA). Culture medium without auxins was used as a control. The number of roots per shoot, length of roots, and rooting percentage were evaluated after 4 weeks of cultivation.

\section{Ex vitro transfer}

Well-rooted shoots were removed from the cultivation jars and the roots were washed with water to remove residues of the culture medium. The plants were transferred into sterile substrate (sand:peat:perlite, 1:1:1) within plastic pots $(7 \times 7 \times 8 \mathrm{~cm})$, watered, and then treated with $1 \%$ Previcur Energy ${ }^{\circledast}$ (propamocarb $530 \mathrm{~g} \mathrm{l}^{-1}$, fosetyl-Al $310 \mathrm{~g} \mathrm{l}^{-1}$ - Bayer Garden, Leverkusen, Germany). The plants were cultivated in a greenhouse under a photoperiod of $16 / 8 \mathrm{~h}$ (day/night) and temperature $24 \pm 2 / 18 \pm 2$ ${ }^{\circ} \mathrm{C}$ (day/night). They were acclimated by gradually decreasing air humidity from $95 \%$ to $60 \%$. One month after the ex vitro transfer, the plants were transferred to partially shaded open growing plots. During the ex vitro cultivation, the plants were fertilized using $0.1 \%$ Kristalon Start (Agro CZ; N-P-K = $19-6-20+3 \% \mathrm{Mg}+7.5 \% \mathrm{~S}+$ microelements $\mathrm{B}$, $\mathrm{Mo}, \mathrm{Fe}, \mathrm{Cu}, \mathrm{Mn}, \mathrm{Zn}$ ) once every 2 weeks during vegetation growth.

\section{Cuttings}

Winter (hardwood) cuttings $10-12 \mathrm{~cm}$ in length were treated with Stimulax ${ }^{\circledR}$ I powder root stimulator (IAA, 3-indoleacetic acid min. $0.06 \%$, NAA min. $0.06 \%$, IBA min. 0.05\% - Hü-Ben, Čerčany, Czech Republic) and Stimulator AS-1 (nicotinic acid min. 1\%, NAA min. $1 \%$ - Nohel Garden, Dobříš, Czech Republic). The basal parts of the cuttings were dipped into the rooting stimulator and planted in substrate composed of peat and sand (1:1). Cuttings not treated with the stimulator were used as control. The cuttings were cultivated in the greenhouse and watered to keep a constant substrate moisture. To prevent fungal infection of the cultures, they were treated with $1 \%$ Previcur Energy ${ }^{\oplus}$ every 2 weeks.

\section{Grafting}

Grafting of B. oycoviensis was performed on $B$. pendula rootstocks at the beginning of March 2018. The rootstock was cut to about $30-40 \mathrm{~cm}$ in length and the winter scions (10-15 cm long) with no shoots were placed on the rootstock at two heights on the side (side-veener graft) or on the top (splice graftor top bark grafting forthicker rootstock). The graft point was tied and fastened by rubber tape and coated with Tervanol $F^{\circledast}$ balsam (turpentine, oil, $1 \%$ thiabendazole, limonene - Dr. Stähler, Schopf $\mathrm{GmbH}$, Bitterfeld-Wolfen, Germany). The plants were left in a transparent plastic foil tunnel until the end of May 2018, then moved to an open growing area. During vegetation, the plants were watered as needed. If newly sprouted shoots (epicormic branches) appeared on the rootstock, these were removed. 
Experimental design and data analysis

For both in vitro multiplication and rooting experiments, 20 explants in two replications were used per treatment and tested genotype. The experiment was set up in a completely randomized design. Percentage success of shoots initiation, length increment of the initial shoots, number of newly created shoots per explant, length of the newly grown shoots, callus formation, number of roots per explant, length of roots, and percentage of rooting were monitored at regular intervals.

For cuttings, 20 explants in two replications were used per treatment and tested genotype. The rooting percentage was evaluated after 6 months.

In grafting, for each genotype, 12 rootstocks were used in two replications. The success of graft acceptance was monitored by genotype and location of the graft.

The significance of differences among means was assessed using Kruskal-Wallis test (as the assumptions of the ANOVA were not satisfied in all cases). Subsequent multiple comparison tests (Siegel \& Castellan 1988) were conducted for identifying statistically significant differences between particular variants.

Binomial testing (Agresti et al. 2008) was used for evaluating the differences between variants where binomial parameters were recorded (i.e., initiation of the culture [yes/no], successful rooting [yes/no], exvitro transfer [successful/unsuccessful], success of grafting [successful/unsuccessful]).

All statistical analyses were conducted using the R software (R Core Team 2017). Significance level ( $\alpha$ ) was set at 0.05 for all analyses. Plots were created using the $\mathrm{R}$ package "ggplot2" (Wickham 2016).

\section{Results and discussion}

\section{In vitro culture}

Our study aimed to compare the success of vegetative propagation in B. oycoviensis using different methods (in vitro cultures especially via meristem cultures -, grafting and cuttings). Particular attention was given to the successful initiation of in vitro culture and propagation of B. oycoviensis. Our study showed the efficacy of the surface sterilization of explants using $0.1 \%$ $\mathrm{HgCl}_{2}$, which prevented the contamination of cultures and their browning. Most authors do not report data about the sterilization success in their studies, but according to Raghu et al. (2006) and Badoni \& Chauhan (2010) $30 \%$ loss of explants is caused by contamination.

The buds started to sprout after 2-3 weeks of cultivation on WP medium supplemented with $1 \mathrm{mg} \mathrm{l}^{-1}$ BAP. Two weeks later, $37.5-87.5 \%$ of the explants of particular genotypes had germinated (Fig. 1). This corresponds to former results reported in the literature (Chalupa 1989, Ryynänen \& Ryynänen 1986, Särkilahti 1988), where lower concentrations of $0.5-2.0 \mathrm{mg} \mathrm{l}^{-1} \mathrm{BAP}$ without addition or auxin or with addition of auxin NAA, IBA, or IAA at concentrations 0.0-0.2 $\mathrm{mg} \mathrm{l}^{-1}$ appeared to be suitable concentrations of cytokinins (BAP) for B. pendula culture. The highest sprouting efficiency was recorded in genotype 540, the lowest in genotype 533 (Fig. 1). During the initial phases of cultivation, explants of some genotypes tended to turn brown and, due to generally slow growth, they did not produce new and viable shoots. Despite regular subculture of the explants onto the fresh medium, all explants of genotypes 518 and 533 died after 2 months, followed by genotypes 34, 520, 521, 540, and 552 three months later. Only for genotypes 516 and 545, the in vitro cultures were successfully maintained and the plants regularly multiplied (Fig. 2a). Therefore, only these two genotypes were used for the multiplication experiment using different concentrations of BAP. Ryynänen \& Ryynänen (1986) had succeeded to grow 2 out of 5 plants to mature trees after micropropagation in curly birch (Betula pendula var. carelica). Contrastingly, Máchová et al. (2012) successfully transferred all (7) individuals taken from the wild to in vitro culture. In our case, only 2 out of 10 tested trees were successfully grown to a mature stage. This demonstrates one of the potential pitfalls of the in vitro culture, as taxon and clone specificity are manifested in micropropagation (Welander 1993).

Ditmar (1991) used various cultivation media for growing curly birch; the best results were achieved on WP medium, as also confirmed by Chalupa (1987), Wynne \& Mc-
Donald (2002), Häggman et al. (2007), Businge et al. (2017), and Girgžde \& Samsone (2017). Cultivation on MS medium has not been so successful (Ditmar 1991, Iliev et al. 2003). On the contrary, Rathwell et al. (2016) reported more promising results in Betula lenta cultures on MS and Driver and Kuniyuki Walnut medium (DKW - Driver \& Kuniyuki 1984) as compared to WP medium. In our case, the shoots were vigorous and green on the control WP medium without BAP supply, but they grew less intensively, reaching just 2 and $4 \mathrm{~mm}$ after 4 and 8 weeks, respectively (Tab. 1). Almost no new shoots developed ( 0.2 and 0.15 shoots per explant, respectively) in genotypes 516 and 545. Callus on the base part of the explants did not develop (Tab. 1).

The plants on WP medium supplemented with $0.5 \mathrm{mg} \mathrm{l}^{-1}$ BAP started to produce new and healthy shoots (1.1 and 1.75 shoots per explant in genotypes 516 and 545, respectively) during 8 experimental weeks while showing no signs of necrosis. The callus started to develop on the plant base. A similar tendency was recorded in plants on culture medium with $1 \mathrm{mg} \mathrm{I}^{-1}$ BAP (2.5 and 3.5 shoots per explant in genotypes 516 and 545, respectively). However, plants subjected to this treatment yielded the highest number of new shoots, as compared with other BAP concentration (Tab. 1, Fig. 2b). The newly produced shoots were green, viable, and without morphological abnormalities. Similarly, Ditmar (1991) used WP medium supplemented with $0.5 \mathrm{mg} \mathrm{l}^{-1}$ BAP to produce 2.9 shoots per explant of curly birch.

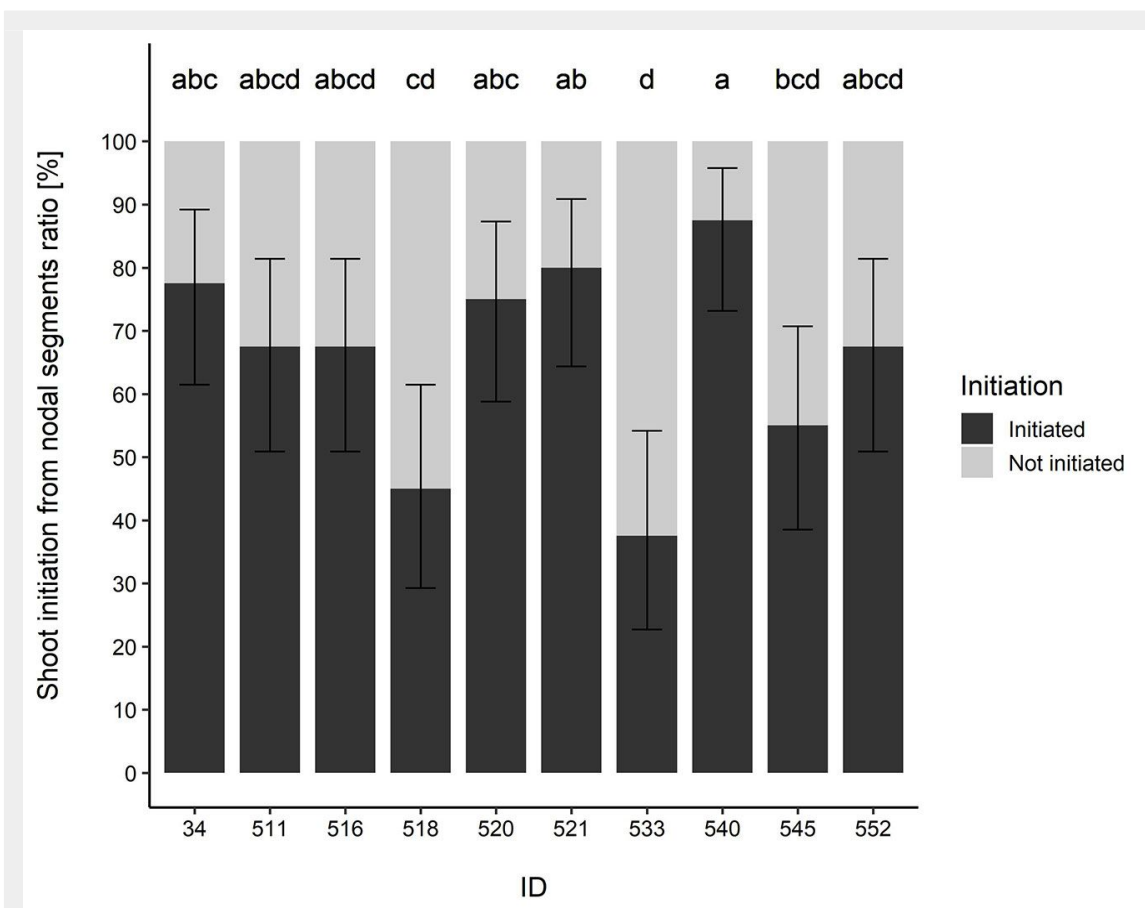

Fig. 1 - Sprouting percentage of nodal segments $(n=40)$ belonging to 10 Betula oycoviensis genotypes, 28 days after their initial cultivation on WP medium supplemented with $1 \mathrm{mg} \mathrm{l}^{-1}$ BAP. Means followed by the same letter within columns do not differ significantly ( $p>0.05)$ after Kruskal-Wallis test. Error bars depict $95 \%$ confidence interval. 


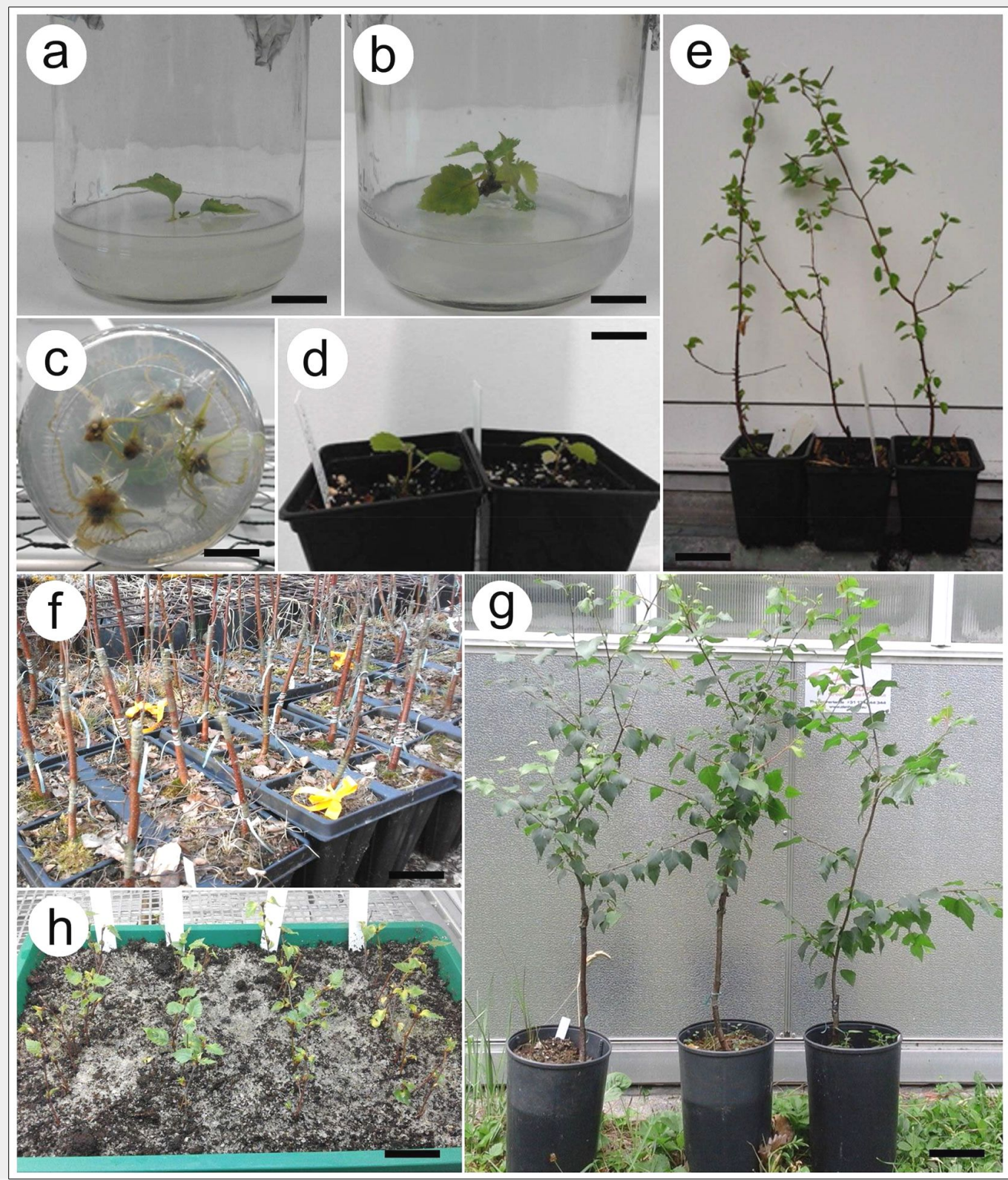

Fig. 2 - (a) Betula oycoviensis initial explant on WP medium with $1 \mathrm{mg} \mathrm{l}^{-1} \mathrm{BAP}$ (scale bar $=1.2 \mathrm{~cm}$ ). (b) B. oycoviensis explant after 8 weeks on WPM medium with $1 \mathrm{mg} \mathrm{l}^{-1} \mathrm{BAP}$ (scale bar $=1.1 \mathrm{~cm}) \cdot(\mathrm{c})$ Rooting explant on $1 / 2$ MS with 0.3 $\mathrm{mg} \mathrm{l}^{-1}$ IBA and $0.3 \mathrm{mg} \mathrm{I}^{-1}$ $\mathrm{NAA}(\mathrm{bar}=1.2 \mathrm{~cm}) .(\mathrm{d})$ Rooted B. oycoviensis plants transplanted into substrate after 4 weeks of acclimatization (scale bar $=$ $1.5 \mathrm{~cm}$ ). (e) Growing B. oycoviensis 8 months old from the in vitro culture (genotype 545 - scale bar = $6 \mathrm{~cm})$. (f) Rootstocks with scions of $B$. oycoviensis in side (side-veneer graft) and top (splice graft or bark grafting) positions (scale bar $=4 \mathrm{~cm}$ ). (g) $\mathrm{B}$. oycoviensis plants 1 year after bark grafting (scale bar $=6.4 \mathrm{~cm})$. (h). Cuttings of B. oycoviensis 8 weeks after culture initiation (scale bar $=4 \mathrm{~cm}$ ).

The callus development was more intensive when BAP concentration was increased beyond $1 \mathrm{mg} \mathrm{l}^{-1}$. Increasing BAP concentration too far beyond that level, however, reduced new shoot development and led to necrosis. Thus, the highest BAP concentration tested $\left(2 \mathrm{mg} \mathrm{l}^{-1}\right)$ led to the production of fewer shoots, which after 34 weeks of cultivation, had brown shoot tips and leaves that also turned brown. This treatment brought the most intensive production of callus seen in the whole experiment. Mirabbasi \& Hosseinpour (2014) report a similar experience with Ulmus glabra, wherein increasing cytokinin concentrations also increased the tendency for callus formation and necroses. When they used no plant growth regulators, neither necroses nor callus were recorded.

The shoots that had developed within the multiplication experiment did not root, and thus they were transferred onto the $1 / 2 \mathrm{MS}$ media containing auxins (IBA, NAA). On culture medium without plant growth reg- ulators, approximately $17.5 \%$ and $22.5 \%$ of shoots rooted for genotype 516 and genotype 545, respectively. Prolonged cultivation of plants on this medium, however, caused browning and death of the plants.

Although the rooting percentage and number of roots per explant increased with auxin concentration, the roots showed poor growth in length (Tab. 2, Fig. 3). Addition of IBA into the culture medium led to formation of callus on the basal part of explants. This phenomenon was not observed in plants cultivated on media with added NAA, but shoot tips of plants cultivated longer on the medium with higher NAA concentration ( $0.5 \mathrm{mg} \mathrm{l}^{-1} \mathrm{NAA}$ ) turned brown and started to wither.

The most efficient rooting medium proved to be half-strength MS medium with a combination of IBA and NAA, both at concentration $0.3 \mathrm{mg} \mathrm{l}^{-1}$ (Fig. 2C). On this medium, we observed the highest rooting percentage for genotypes 516 and 545 (72.5\% and $77.5 \%$, respectively - Fig. 3) and the highest number of roots per explant (4.5 and 5.7, respectively - Tab. 2). Wynne \& McDonald (2002) reported 60-100\% Betula pendula rooting percentage in relation at IBA concentration of $0-0.3 \mathrm{mg} \mathrm{l}^{-1}$. Máchová et al. (2012) reported 100\% rooting efficiency in Betula nana grown on WP medium with $0.5 \mathrm{mg} \mathrm{l}^{-1}$ IBA. Successful rooting results of Betula pubescens are also reported by Kauppi et al. (1999) and by Wakita et al. (1996) in Betula platyphylla on MS medium with IBA auxin ( $\left.0.5 \mathrm{mg} \mathrm{l}^{-1}\right)$ and NAA $\left(0.02 \mathrm{mg} \mathrm{l}^{-1}\right)$.

Rooted shoots were transferred ex vitro and acclimated in the greenhouse. Plants rooted on all types of media were included into this experiment. Eight weeks after ex vitro transfer (Fig. 2d), at least $90 \%$ of plants were still surviving (100\% of plants in the case of all rooting media, $90 \%$ of plants from the control medium - Fig. 2e). Similarly, Máchová et al. (2012) reported 98\% success in ex vitro transfer in the case of $B$. nana. Rathwell et al. (2016) reported that 
acclimatization of $B$. lenta was poor with only $36.8 \%$ success, even though the in vitro rooting efficiency had been $80 \%$ on $1 / 2$ MS and $1 / 2$ DKW medium with $4.1 \mathrm{mg} \mathrm{I}^{-1}$ IBA. In our experiment, no differences in plant survival were observed among plants from various rooting media. All plants kept growing, new leaves developed, and no abnormalities were observed.

\section{Cuttings}

Hardwood cuttings of B. oycoviensis treated with root stimulators were transferred to the greenhouse (Fig. 2h) as described above. The cuttings were evaluated at the end of the vegetative season in 2018. No roots developed on any of the cuttings and no callus development on the basal part of the cuttings was observed (regardless they were treated with root stimulators or not). Hartmann \& Kester (1975) had stated that birch cuttings are difficult to root due to low species-specific rooting potential. Similarly, Václav (1973) reported that in curly birch winter cutting growth was not very successful. Winter cuttings of this species usually take longer to root (even as long as 2 years) than do summer cuttings from trees over 3 years of age. Marczynski \& Joustra (1993) used Rhizopon ${ }^{\circledast}$ AA powder containing $2 \%$ IBA for rooting and achieved $96-99 \%$ successfully rooted cuttings of $B$. utilis, $77-85 \%$ of which survived until the following year. Unlike our study, the aforementioned experiments used young plant material for vegetative propagation. Nevertheless, cuttings collected from older trees are generally regarded as difficult to root (Hartmann et al. 2002, Pijut et al. 2010).

\section{Grafting}

A partial success with variable results were observed for B. oycoviensis grafted onto silver birch rootstock (Fig. 2f). The best results were achieved with genotype 34. At the end of the vegetation season, $50 \%$ of the grafted trees from that genotype were assessed as successfully growing. The success rate was $33 \%$ in genotypes 520 and 545 , and $8 \%$ in genotype 521 . The grafts on rootstocks of the mentioned trees grew without abnormalities during the growing season and created a new assimilation apparatus and new shoots (Fig. $2 \mathrm{~g}$ ). No inosculated graft was found at the end of the 2018 vegetation season on the other grafted trees. The position of the graft (side vs. top) did not significantly affect the success of the inosculation, as well as the position of the scion (side vs. top). In fact, an identical $33 \%$ success rate was achieved for scions growing in (i) both side and top position, (ii) only in the side position, or (iii) only in the top position.

Jermakov (1970) used curly birch scions grafted onto wild birch rootstocks 4-5 years old in open areas, achieving the highest success rate of $60 \%$ with the best clone and $26 \%$ success on average. The same author further reported that grafting in the
Tab. 1 - Effect of benzylaminopurine (BAP) concentrations on new shoot development within 8 weeks of in vitro cultivation of Betula oycoviensis explants $(n=40)$. Means followed by the same letter within columns do not differ significantly $(P>0.05)$ after Kruskal-Wallis test. Data were recorded after 8 weeks of culture. (-): no callus; ( $\left.{ }^{*}\right)$ : little callus; $(* *)$ : moderate callus; $(* * *)$ : large callus.

\begin{tabular}{|c|c|c|c|c|c|c|}
\hline \multirow[t]{2}{*}{$\begin{array}{c}\text { Nutrient } \\
\text { media }\end{array}$} & \multirow{2}{*}{$\begin{array}{c}\text { BAP } \\
\text { Conc. } \\
\left(\mathrm{mg} \mathrm{l}^{-1}\right)\end{array}$} & \multirow[t]{2}{*}{$\begin{array}{l}\text { Geno- } \\
\text { type }\end{array}$} & $\begin{array}{l}\text { Length increment } \\
\text { of initial shoots } \\
(\mathrm{mm})\end{array}$ & $\begin{array}{l}\text { Number of } \\
\text { new shoots / } \\
\text { explant }\end{array}$ & $\begin{array}{l}\text { Length of } \\
\text { new shoots } \\
(\mathrm{mm})\end{array}$ & \multirow[t]{2}{*}{$\frac{\mathscr{\nu}}{\bar{J}}$} \\
\hline & & & (mean \pm SD) & $($ mean $\pm S D)$ & $($ mean $\pm S D)$ & \\
\hline \multirow{2}{*}{ WP } & \multirow[b]{2}{*}{0} & 516 & $4.60 \pm 2.93^{b c}$ & $0.20 \pm 0.40^{b c}$ & $1.05 \pm 2.18^{c}$ & - \\
\hline & & 545 & $4.10 \pm 1.99^{c}$ & $0.15 \pm 0.36^{c}$ & $0.90 \pm 2.30^{c}$ & - \\
\hline \multirow{2}{*}{ WP } & \multirow{2}{*}{0.5} & 516 & $9.80 \pm 3.75 a b$ & $1.10 \pm 0.62 \mathrm{ab}$ & $6.68 \pm 3.21 \mathrm{ab}$ & * \\
\hline & & 545 & $14.45 \pm 2.56^{\mathrm{ad}}$ & $1.75 \pm 0.69^{\text {ad }}$ & $7.83 \pm 2.80^{b}$ & * \\
\hline \multirow{2}{*}{ WP } & \multirow{2}{*}{1} & 516 & $12.15 \pm 5.58^{a}$ & $2.50 \pm 1.02^{a}$ & $6.90 \pm 2.28 \mathrm{ab}$ & $* *$ \\
\hline & & 545 & $18.80 \pm 3.25^{d}$ & $3.50 \pm 1.12^{d}$ & $7.50 \pm 2.81^{b}$ & $* *$ \\
\hline \multirow{2}{*}{ WP } & \multirow[b]{2}{*}{$Z$} & 516 & $10.30 \pm 3.70^{a}$ & $2.20 \pm 0.68^{a}$ & $5.39 \pm 1.51^{a}$ & . \\
\hline & & 545 & $11.10 \pm 2.55^{a}$ & $2.10 \pm 0.83^{a}$ & $5.59 \pm 1.86^{a}$ & $* * *$ \\
\hline
\end{tabular}



Fig. 3 - Effect of auxins on rooting of Betula oycoviensis shoots $(n=40)$ belonging to genotypes 516 and 545 after 28 days of their cultivation on half-strength MS medium. Means followed by the same letter within columns do not differ significantly $(P>0.05)$ after Kruskal-Wallis test. Error bars depict 95\% confidence interval.

Tab. 2 - Effect of indole-3-butyric acid (IBA) and a-naphthylacetic acid (NAA) concentrations on new root development within 4 weeks of in vitro cultivation of Betula oycoviensis explants $(n=40)$. Means followed by the same letter within columns do not differ significantly $(\mathrm{P}>0.05)$ after Kruskal-Wallis test. Data were recorded after 4 weeks of culture.

\begin{tabular}{|c|c|c|c|c|c|}
\hline \multirow{2}{*}{$\begin{array}{l}\text { Nutrient } \\
\text { medium }\end{array}$} & \multicolumn{2}{|c|}{$\begin{array}{c}\text { Concentration } \\
\left(\mathrm{mg} \mathrm{l}^{-1}\right)\end{array}$} & \multirow[t]{2}{*}{ Genotype } & \multirow{2}{*}{$\begin{array}{c}\text { Number of roots } \\
\text { by explant }\end{array}$} & \multirow{2}{*}{$\begin{array}{l}\text { Root lengths } \\
\text { (cm) } \\
\text { (mean } \pm \text { SD) }\end{array}$} \\
\hline & IBA & NAA & & & \\
\hline \multirow[b]{2}{*}{$1 / 2 M S$} & \multirow[b]{2}{*}{0} & \multirow[b]{2}{*}{0} & 516 & $0.20 \pm 0.40^{\mathrm{a}}$ & $1.12 \pm 0.48^{a}$ \\
\hline & & & 545 & $0.25 \pm 0.43^{a b}$ & $1.42 \pm 0.56^{a b}$ \\
\hline \multirow{2}{*}{$1 / 2 M S$} & \multirow{2}{*}{0.3} & \multirow{2}{*}{0} & 516 & $0.50 \pm 0.92^{a b}$ & $0.95 \pm 0.45^{\mathrm{ab}}$ \\
\hline & & & 545 & $0.80 \pm 1.17 \mathrm{ab}$ & $1.16 \pm 0.44$ \\
\hline \multirow{2}{*}{$1 / 2 M S$} & \multirow[b]{2}{*}{0.5} & \multirow{2}{*}{0} & 516 & $1.75 \pm 1.99 a b c$ & $1.09 \pm 0.46^{b c}$ \\
\hline & & & 545 & $2.55 \pm 2.46^{\mathrm{abcd}}$ & $1.27 \pm 0.60^{c}$ \\
\hline \multirow{2}{*}{$1 / 2 M S$} & \multirow{2}{*}{0} & \multirow{2}{*}{0.3} & 516 & $2.60 \pm 2.40^{a b c d}$ & $0.93 \pm 0.34^{b c}$ \\
\hline & & & 545 & $2.70 \pm 2.32 \mathrm{abcd}$ & $1.05 \pm 0.41^{c}$ \\
\hline \multirow{2}{*}{$1 / 2 M S$} & \multirow{2}{*}{0} & \multirow{2}{*}{0.5} & 516 & $2.85 \pm 2.55^{\mathrm{abcd}}$ & $0.98 \pm 0.39^{c}$ \\
\hline & & & 545 & $3.65 \pm 2.59^{\mathrm{bcd}}$ & $1.03 \pm 0.40^{c}$ \\
\hline \multirow{2}{*}{$1 / 2 M S$} & \multirow{2}{*}{0.3} & \multirow{2}{*}{0.3} & 516 & $4.55 \pm 3.12^{\mathrm{cd}}$ & $0.81 \pm 0.27^{b c}$ \\
\hline & & & 545 & $5.70 \pm 3.05^{d}$ & $0.79 \pm 0.25 b c$ \\
\hline
\end{tabular}


greenhouse had an average success rate of $52 \%$, and several clones showed as much as $100 \%$ success in inosculation and subsequent growth. Ljubavskaja (1966) summarized her numerous experiments with curly birch grafting and concluded the best grafting method to be the side-veneer in $B$. pubescens and possibly in $B$. verrucosa. The diameter of the graft should be $>4 \mathrm{~mm}$ and length 4-5 cm, bearing 3-4 buds. The root material (rootstock) should be 4-5 years old with a stem diameter of $3-5 \mathrm{~cm}$, and the best period for transplantation is in February. Václav (1973) used 2-year-old B. pendula rootstocks grafted in January and $93 \%$ of the curly birch grafts successfully inosculated. Ranney \& Whitman (1995) investigated the possibility of vegetatively propagating B. platyphylla var. japonica via its scion grafted onto various birch rootstocks (B. nigra, B. papyrifera, B. szechuanica, and $B$. pendula). They obtained the best results using B. nigra as rootstock, whereby $100 \%$ of the grafts survived for 2 years after grafting. That was in contrast with $B$. pendula, upon which only $80 \%$ of the grafts survived. The poorest results were achieved with B. szechuanica, where only $30 \%$ of the grafts survived. Choice of a suitable grafting rootstock is therefore of great importance.

\section{Conclusion}

Our results on the vegetative propagation of B. oycoviensis via organogenesis and grafting suggest a real possibility for successfully addressing the need to maintain the $B$. oycoviensis gene pool. Consideration should be given to conducting further research in the field of cuttings (especially in relation to summer cuttings) and for further improving the growth of explants in vitro. Selected results of this study can point to further directions in investigating the reproduction of birches and other genera by vegetative propagation, through in vitro cultures, grafting, and cutting.

\section{List of abbreviations}

The following abbreviations have been used throughout the text:

- BAP: 6-benzylaminopurine;

- IAA: 3-indoleacetic acid;

- DKW: Driver and Kuniyuki (1984) medium;

- IBA: indole-3-butyric acid;

- MS: Murashige \& Skoog (1962) medium;

- NAA: a-naphthylacetic acid;

-WP: Lloyd \& McCown (1980) medium.

\section{Authors' Contributions}

$J V$ and IK conceived and designed the experiments; $M B$ and RL collected the samples and evaluated the different traits on the trees. RL did the statistical analysis of the data. JV, IK and IV wrote the manuscript with the assistance of the other authors.

\section{Acknowledgements}

This work was supported by the TA CR agency (Project No. TACR TH03030339).
Technical facilities for experiments were provided by the in vitro laboratory of the Faculty of Forestry and Wood Sciences and nursery facilities by the Department of Silviculture in Truba, Kostelec nad Cernými lesy (Czech Republic). We thank English Editorial Services and Environmental English Ltd. for proofreading of the manuscript.

\section{References}

Agresti A, Bini M, Bertaccini B, Ryu E (2008). Simultaneous confidence intervals for comparing binomial parameters. Biometrics 64: 1270-1275. doi: 10.1111/j.l541-0420.2008.00990.x

Andrews PK, Marquez CS (1993). Graft incompatibility. Horticultural Reviews 15: 183-231. [online] URL: http://books.google.com/books?id=y OOCkpwdiJoC

Badoni A, Chauhan JS (2010). In vitro sterilization protocol for micropropagation of Solanum tuberosum cv. "Kufri Himalini". Academia Arena 2 (4): $24-27$.

Baláš M, Kuneš I, Gallo J, Rašáková N (2016). Review on Betula oycoviensis and foliar morphometry of the species in Volyně, Czech Republic. Dendrobiology 76: 117-125. - doi: 10.12657/den bio.076.011

Buriánek V, Novotný P, Frýdl J (2014). Metodická př́ručka k určování domácích druhůbříz. Certifikovaná metodika [Methodological manual for native birch species determination]. Lesnický průvodce 3/2014. Výzkumný ústav lesního hospodárství a myslivosti, v. v. i., pp. 40. [in Czech] Businge E, Trifonova A, Schneider C, Rödel P, Egertsdotter U (2017). Evaluation of a new temporary immersion bioreactor system for micropropagation of cultivars of Eucalyptus, birch and fir. Forests 8 (6): 196. - doi: 10.3390/f8060 196

Darikova JA, Savva YV, Vaganov EA, Grachev AM, Kuznetsova GV (2011). Grafts of woody plants and the problem of incompatibility between scion and rootstock (a review). Journal of Siberian Federal University - Biology 1 (4): 54-63. [online] URL: http://cyberleninka.ru/article/n/ grafts-of-woody-plants-and-the-problem-of-in compatibility-between-scion-and-rootstock-areview/viewer

De Diego N, Montalbán IA, Moncaleán P (2010). In vitro regeneration of adult Pinus sylvestris $L$. trees. South African Journal of Botany 76 (1): 158-162. - doi: 10.1016/j.sajb.2009.09.007

Ditmar O (1991). In vitro regeneration of curly birch, Betula pendula var. carelica. Thaiszia Journal of Botany 1: 119-124.

Driver JA, Kuniyuki AH (1984). In vitro propagation of Paradox walnut Juglans hindsii $\times$ Juglans regia rootstock. HortScience 19: 507-509.

Girgžde E, Samsone I (2017). Effect of cytokinins on shoot proliferation of silver birch (Betula pendula) in tissue culture. Environmental and Experimental Biology 15: 1-5. - doi: 10.22364/ee b.15.01

Grulich V (2012). Red list of vascular plants of the Czech Republic ( $3^{\text {rd }}$ edn). Preslia 84 (3): 631645. [online] URL: http://www.cabdirect.org/ cabdirect/abstract/20123395488

Hartmann HT, Kester DE, Davies FT, Geneve R (2002). Plant propagation, principles and practices $\left(7^{\text {th }}\right.$ edn). Prentice-Hall, Englewood Cliffs, NJ, USA, pp. 880.
Hartmann HT, Kester DE (1975). Plant propagation, principles and practices $\left(3^{\text {rd }}\right.$ edn). PrenticeHall, Englewood Cliffs, NJ, USA, pp. 662.

Häggman H, Sutela S, Welander M (2007). Micropropagation of Betula pendula Roth including genetically modified material. In: "Protocols for micropropagation of woody trees and fruits" (Jain SM, Häggman $\mathrm{H}$ eds). Springer, Dordrecht, Netherlands, pp. 153-162. - doi: 10.1007 / 978-1-4020-6352-7_15

Chalupa V (1987). European Hardwoods. In: "Cell and Tissue Culture in Forestry" (Bonga JM, Durzan DJ eds). Forestry Sciences, vol. 24-26, Springer, Dordrecht, Netherlands, pp. 224-246. - doi: 10.1007/978-94-017-0992-7_17

Chalupa V (1989). Micropropagation of mature trees of birch (Betula pendula Roth.) and aspen (Populus tremula L.). Lesnictví 35: 983-993.

Iliev I, Scaltsoyiannes A, Rubos A (2003). Shoot organogenesis and plant regeneration from leaf callus cultures of black bark silver birch (Betula pendula Roth. "Melanocortea"). Acta Horticulturae 616: 321-326. - doi: 10.1766o/actah ortic.2003.616.45

Jermakov VI (1970). Razmnozhenie berezy karel'skoj metodom privivki [Propagation of Karelian birch by the grafting method]. Lesnaya Genetika, Selekcia i Semenovodstvo, Petrozavodsk, pp. 282-293. [in Russian]

Kaplan Z (2019). Klíč ke květeně České republiky [Key to the flora of the Czech Republic]. Revised and updated edition, Academia, Prague, Czech Republic, pp. 1172. [in Czech]

Kauppi A, Kauppi M, Ulvinen T (1999). A new columnar form of Betula pubescens from Finland: mophological characteristics and micropropagation. Annales Botanici Fennici 36: 33-41. [online] URL: http://www.jstor.org/stable/2372 6645

Korczyk A (1967). Rozmieszczenie geograficzne brzozy ojcowskiej (Betula oycoviensis Bess.) [Geographic distribution of Oyców birch (Betula oycoviensis Bess.)]. Ochrona Przyrody 32: 133-170. [in Polish]

Krzaczek W, Krzaczek T (1968). New locality of Betula oycoviensis Bess. in Poland. Fragmenta Floristica et Geobotanica 14: 155-156.

Kříž Z (2003). Betula L. - bříza: Květena České republiky, část II [Betula L. - birch: Flora of the Czech Republic, Part II] (Hejný S, Slavík B eds). Academia, Prague, Czech Republic, pp. 35-46. [in Czech]

Kubát K, Hrouda L, Chrtek J, Kaplan Z, Kirschner J, Štěpánek J (2002). Klíč ke květeně České Republiky [Key to the Flora of the Czech Republic]. Academia, Prague, Czech Republic, pp. 928. [in Czech]

Kuneš I, Linda R, Fér T, Karlík $P$, Baláš $M$, Ešnerová J, Vítámvás J, Bílý J, Urfus T (2019). Is Betula carpatica genetically distinctive? A morphometric, cytometric and molecular study of birches in the Bohemian Massif with a focus on Carpathian birch. PLoS ONE 14(10): e0224387. doi: 10.1371/journal.pone.0224387

Ljubavskaja AJ (1966). Selekciya i razvedenie karel'skoj berezy [Selection and breeding of Karelian birch]. Lesnaya Promyslennost, Moskva, Russia, pp. 123. [in Russian]

Lloyd G, McCown B (1980). Commercially-feasible micropropagation of mountain laurel, Kalmia latifolia, by use of shoottip culture. Com- 
bined Proceedings, International Plant Propagators' Society 30: 421-427. [online] URL: http:// www.cabdirect.org/cabdirect/abstract/1983031 5515

Máchová P, Malá J, Cvrčková H (2012). Mikropropagace břízy trpasličí [Micropropagation of Betula nana]. Zprávy lesnického výzkumu 57: 202-206. [in Czech]

Marczynski S, Joustra MK (1993). Influence ofdaylength and irradiance on growth of the stock plants and subsequent rooting of cuttings of Betula utilis D. Don. and Corylus maxima Mill. cultivar "Purpurea". Scientia Horticulturae 55: 291-301. - doi: 10.1016/0304-4238(93) 90040-W

Mirabbasi AM, Hosseinpour B (2014). Prevention of shoot tip necrosis, hyperhydricity and callus production associated with in vitro shoot culture of Ulmus glabra. Journal of Novel Applied Sciences 3 (6): 683-689. [online] URL: http:// jnasci.org/wp-content/uploads/2014/06/683-68 9.pdf

Murashige T, Skoog F (1962). A revise medium for rapid growth and bioassays with tobacco tissue cultures. Physiologia Plantarum 15: 473497. - doi: 10.1111/j.1399-3054.1962.tbo8052.x Pellett NE, Alpert K (1985). Rooting softwood cuttings of mature Betula papyrifera. Combined proceedings, International Plant Propagators' Society 35: 519-525.

Pijut PM, Woeste KE, Michler CH (2010). Promotion of adventitious root formation of difficultto-root hardwood tree species. In: "Horticultural reviews", vol. 38 (Janick J ed). John Wiley and Sons, Hoboken, NJ, USA, pp. 213-251. - doi: 10.1002/9780470872376.ch6

Pritchard HW, Moat JF, Ferraz JBS, Marks TR, Luís J, Camargo C, Nadarajan J, Ferraz IDK (2014). Forest ecology and management innovative approaches to the preservation of forest trees. Forest Ecology and Management 333: 88-98. - doi: 10.1016/j.foreco.2014.08.012

Raghu AV, Geetha SP, Martin G, Balachandran I, Ravindran PN (2006). In vitro clonal propagation through mature nodes of Tinospora cordifolia (Willd.) Hook. F. and Thoms.: an important ayurvedic medicinal plant. In Vitro Cellular and Developmental Biology - Plant 42: 584-588. doi: $10.1079 /$ IVP2006824

Rathwell R, Shukla MR, Jones MP, Saxena PK (2016). In vitro propagation of cherry birch (Betula lenta L.). Canadian Journal of Plant Science 96: 571-578. - doi: 10.1139/cjps-2015-0331

Ranney TG, Whitman EPII (1995). Growth and survival of "Whitespire" Japanese birch grafted on rootstocks of five species of birch. HortScience 30 (3): 521-522. - doi: 10.21273/HORTSCI. 30.3.521

R Core Team (2017). R: a language and environment for statistical computing. R Foundation for Statistical Computing, Vienna, Austria. [online] URL: http://www.R-project.org/

Ryynänen L, Ryynänen M (1986). Propagation of adult curly birch succeeds with tissue culture. Silva Fennica 20: 139-147. - doi: 10.14214/sf.a1 5448

Särkilahti E (1988). Micropropagation of a mature colchicine - polyploid and irradiation - mutant of Betula pendula Roth. Tree Physiology 4: 173-179. - doi: 10.1093/treephys/4.2.173

Siegel S, Castellan NJ (1988). Non parametric statistics for the behavioural sciences. MacGraw Hill Int., New York, USA, pp. 399.

Sota V, Kongjika E (2014). The effect of nutrient media in micropropagation and in vitro conservation of wild population of mahaleb cherry (Prunus mahaleb L.). The Journal of Microbiology, Biotechnology and Food Sciences 3 (6): 453-456. [online] URL: http://www.researchga te.net/publication/325066671
Staszkiewicz J, Wójcicki JJ (1992). "Betula x oycoviensis" Besser in the environs of Kraków (S. Poland). Veröffentlichungen des Geobotanischen Institutes der Eidgenössische Technische Hochschule, Stiftung Rübel, Zürich 107: 94-97.

Staszkiewicz J (2013). Brzoza ojcowska (Betula oycoviensis Bess.) na górze Skielek w Beskidzie Wyspowym [Ojcow birch (Betula oycoviensis Bess.) on Skielek Mountain in the Beskid Wyspowy]. Web site. [in Polish] [online] URL: http://archive.is/LRuuR

Václav E (1973). Vegetative propagation of birch. New Zealand Journal of Forestry Science 4 (2): 237-241.

Viherä-Aarnio A, Velling P (2001). Micropropagated silver birches (Betula pendula) in the field - performance and clonal differences. Silva Fennica 35: 385-401. - doi: 10.14214/sf.576

Wakita Y, Sasamoto H, Yokota S, Yoshizawa N (1996). Plant regeneration from cell suspension cultures of Betula platyphylla var. Japonica. Plant Tissue Culture Letters 13: 49-54. - doi: 10.5511/plantbiotechnology1984.13.49

Welander M (1993). Micropropagation of Birch. In: "Micropropagation of woody plants" (Ahuja MR eds). Kluwer Academic Publishers, Dordrecht, Netherlands, pp. 223-246. - doi: 10.1007/ 978-94-015-8116-5_14

Wickham H (2016). ggplot2: elegant graphics for data analysis. Springer-Verlag, New York, USA, pp. 213. [online] URL: http://books.google.com/ books?id=XgFkDAAAQBAJ

Wynne J, McDonald MS (2002). Adventitious root formation in woody plant tissue: The influence of light and indole-3-butyric acid (IBA) on adventitious root induction of Betula pendula. In Vitro Cellular and Developmental Biology Plant 38: 210-212. - doi: 10.1079/IVPIVP2001266 